Kara Özkan, N. (2021). Türkçe öğretmenlerinin ders kitaplarına bağlılıklarına yönelik öğretmen görüşleri. Ana Dili Eğitimi Dergisi, 9(1), 131-150.

Ana Dili Eğitimi Dergisi
Journal of Mother Tongue Education
Www.anadiliegitimi.com
Geliş/Received: 12.09 .2020 Kabul/Accepted:22.01.2021
Araştırma Makalesi / Research Paper

\title{
Türkçe Öğretmenlerinin Ders Kitaplarına Bağlılıklarına Yönelik Öğretmen Görüşleri ${ }^{*}$
}

\author{
Neşe KARA ÖZKAN**
}

Öz

Bu çalışmada Türkçe öğretmenlerinin Türkçe ders kitaplarına bağlııklarına yönelik görüşleri ele alınmıştır. Bunun için yarı yapılandırıımış görüşme formu hazırlanmıştır. Aksaray ilinde 6 farkı ortaokulda görev yapan 20 Türkçe öğretmeni ile görüşülmüştür Görüşme kayıtları araştırmacı tarafından dinlenerek bilgisayarda yazıımış ve bu dokümanlar üzerinde içerik analizi yapılmıştır. Analiz sonunda kodlar ve frekans dağılımları belirlenmiştir. Kodlar üzerinden tespit edilen temalar şunlardır: Metin kullanımı, etkinlikler, alan bilgisi, öğrenci seviyesi ve yaratıcılıktır. Metin kullanımı temasında öğretmenlerin hepsi ders kitaplarına bağlı kalmaktadır. Etkinler temasında da öğretmenlerin her zaman önceliği ders kitabıdır, gerekli gördükleri durumlarda ders kitabı dışında farklı kaynaklardan yararlanmaktadırlar. Türkçe öğretmenlerinin çoğu alan bilgisi konusunda ders kitaplarını yetersiz görmekte ve bazıları da bu nedenle farklı kaynaklar kullanmaktadırlar. Öğrenci seviyesi ne olursa olsun ders kitaplarına bağlı kalmaktadırlar ancak akademik başarı düzeyi yüksek öğrenciler için farklı kaynaklar kullanmaktadırlar. Öğretmenin yaratıcılığında da katılımcıların \%55'i Türkçe ders kitabına koşulsuz bağlılığın öğretmenin yaratıcılığını olumsuz yönde etkilediğini ifade etmişlerdir.

Anahtar Kelimeler: Türkçe öğretimi, ders kitabına bağlıık, öğretmen görüşleri, ders kitaplarından yararlanma

\section{Turkish Language Teachers' Opinions About Commitment to Turkish Textbooks Abstract}

In this study, opinions of Turkish language teachers about their dependence on Turkish language textbooks have been received. A semi-structured interview form has been prepared for this. Interviews have been made with 20 Turkish language teachers from 6 different secondary schools in Aksaray province. The recordings of those interviews have been written out by the researcher, and content analysis has been made on them. The themes that were identified after the analysis are these: use of text, tasks, field information, student level and creativity. Scripts and frequency distribution were designated depending on these themes. In the use of text theme, all of the teachers abide by the textbooks. Teachers always give the priority to the textbooks in the tasks theme as well, but they take the advantage of some reference books other than the textbooks when it is needed. Most of the Turkish language teachers consider the textbooks insufficient on the field information, thus some of them use different sources. Within the context of student level, they stick to the textbooks regardless of what the level is, but they use different sources for students with better academic achievement levels. In the creativity theme, fifty five percent of participants remark that the Turkish language textbooks affect the creativity of teachers in a negative way.

Keywords: Turkish language teaching, dependence on textbooks, opinions of teachers, making use of textbooks

\footnotetext{
*Etik Kurul İzni: Aksaray İl Milli Eğitim Müdürlüğü, 20.05.2020, 85705372-44-E.7047484

${ }^{* *}$ Dr., Aksaray il Millî Eğitim Müdürlüğü, ARGE, Aksaray, ns_kr@hotmail.com, ORCID: 0000-0001-7639-9773
} 


\section{Giriş}

Ders kitabı, belirli bir eğitim programı çerçevesinde verilmesi hedeflenen kazanımların yerleşmesi için kullanılan bir araçtır. Öğrenci açısından bakıldığında da öğrenilmek istenen bilgilerin ve bu bilgilerle ilgili uygulamaların bulunduğu bir kaynaktır. Cunningsworth'e (1995)e göre ders kitabı öğrenci ihtiyaçlarına yönelik önceden belirlenmiş hedefleri sağlayan kaynaktır. Ders kitabı, yıllardır eğitimin hangi alanında olursa olsun bilgi aktarımında ve geliştirilmesi hedeflenen becerilerin istenilen düzeye gelmesinde en önemli araç olarak kullanılmaktadır. Grant (1987) ders kitaplarının rollerini şöyle ifade etmektedir:

1. "Ne öğretilmesi / öğrenilmesi gerektiğini ve hangi sırada öğretilmesi / öğrenilmesi gerektiğini belirleyebilir,

2. Hangi yöntemin kullanılması gerektiğini belirleyebilir,

3. Ihtiyaç duyulan tüm materyalleri düzenli, çekici ve ekonomik bir biçimde sağlayabilir,

4. Ögretmenlere oldukça zaman kazandırabilir,

5. Öğrenciler için çok faydalı bir yardımcı rolü üstlenebilir."

Ders kitabı, öğrencilerin konulara ilişkin bilgileri belli bir sırada ve amacına uygun olarak öğrenmeleri adına öğretim programı kapsamında hazırlanmış yazııı materyallerdir. Kitaplar, öğretim ortamında öğretmenin gücünü daha iyi kullanmasına ve sistematik bilgiler sunmasına olanak veren araçlardır ve bu nedenle vazgeçilemez bir yeri vardır (Ünveren Kapanadze, 2018). Ders kitabı, eğitim felsefelerinin yönlendirdiği eğitim programlarının en önemli somut ürünüdür (Hayırsever, 2010).

Cunningham, Duffy ve Knuth (2000) gibi uzmanlar, ders kitaplarının öğretmen merkezli yaklaşımdan uzak olması gerektiğini savunmaktadırlar. Ders kitapları öğrencinin okuyup anlamasına, eleştirmesine, sorgulamasına imkân tanıyacak nitelikte olmalıdır. İletişim teknolojilerinin hızla ilerlediği günümüzde bilgiye ulaşmak oldukça kolaylaşmıştır. Ders kitapları bilgi kaynağı olma işlevinin yanı sıra öğrencilerin düşünme, yorumlama, sorun çözme, karşılaştırma gibi becerilerinin gelişimine kaynaklık edecek niteliklere sahip olmalıdır. Ders kitabı, belirlenen hedefe ulaşmak için kullanılan bir araçtır. Bu aracın en önemli niteliklerinden biri işlevsel olmasıdır.

Ders kitapları işlenecek konu ile ilgili olarak öğrencilere ders öncesinde birtakım hazırlıklar yapma olanağı sunar. Bu durum onların hazır bulunuşluklarını da etkilemektedir. Bunun dışında ders kitabı, öğrencinin derse etkin katılımının sağlanmasında da faydalıdır. Çünkü gerek ön hazırlık sürecinde gerekse dersin işlenişinde öğrenci katılımını desteklediğinden eğitim-öğretim sürecinde gerekli ve önemli bir araçtır. Ders kitaplarının kolay ulaşılabilir olma ve kullanma kolaylığı sağlaması sebebiyle işlevsel olarak kullanılabilmesi öğrenmenin gerçekleşmesinde ve kalıcılığının sağlanmasında oldukça önemlidir (Kılıç ve Seven, 2002).

Ders kitaplarının kullanılmasının çeşitli nedenleri bulunmaktadır. İlk neden, dersin düzenli bir biçimde sürdürülmesidir. İkinci neden kitabın bir öğretim aracı olarak kullanılmasıdır. Üçüncü neden ise ders kitabının kullanışıı bir araç olmasıdır (Yanpar Şahin ve Yıldıım, 1999). Ders kitabı, öğretmen ve öğrencilerin kaynak kullanımı açısından bir ortaklık sağlayacağından konunun dağımasını önlemekte ve eğitim sürecinin merkezîleşmesini, bir başka deyişle odak noktasının belirginleşmesini sağlamaktadır. Böylelikle öğrencinin dikkatinin içerik üzerinde odaklanmasını ve dersin içeriği üzerinde bir birlikteliğin oluşmasını mümkün kılarken, sorunların çözümünde ve paylaşımın organizasyonunda merkez noktasını oluşturmaktadır.

Türkçe dersi, bireyin iletişim becerisini geliştiren ve onun toplumsallaşmasında katkı sağlayan temel derslerden biridir. Ayrıca Türk kültürünün yeni kuşaklarca benimsenmesinde ve toplumsal varlığın güç kazanarak sürdürülmesinde önemlidir (Susar Kırmızı, 2014). Bunlar da ancak metinler aracılı̆̆ıyla sağlanabilir. Öğrencilerin okuyarak ve dinleyerek edindiklerini anlamaları, düşüncelerini ifade edebilmeleri için Türkçe dersinde temel araç olan metinler, anlama ve anlatma çalışmalarının yürütüldüğü ana malzemelerdir (Baş, 2003). Yazıcı ve Kurudayıoğlu (2017), araştırmalarında beşinci sınıf ders kitaplarında bulunan dinleme metinlerini iki ayrı başlık altında incelemiş, buna göre hikâye edici metinlerin öğrenci seviyeleri bakımından iyi düzeyde bulurken, bilgilendirici metinlerin öğrencilerin - bilhassa erkek öğrencilerin - seviyelerine göre zor anlaşıldığını tespit etmişlerdir. Kaya (2020), kısa metinlerin öğrenciler tarafından anlaşımasının daha kolay olduğunu belirtmektedir. Başaran ve Akyol'a (2009) göre öğrenciler hikâye edici metinleri bilgilendirici metinlere göre daha iyi 
anlamaktadırlar. Çelik, Demirgüneş ve Fidan (2015) çalışmalarında, metin seçiminde titiz davranılması gerektiğini vurgulayarak öğrencilere sunulacak metinlerin onların okuduklarını anlama becerilerinin gelişmesi ve okuma alışanlığı kazandırılmasında etkili olduğundan iyi yapılandırılmış olmaları gerektiğini belirtmektedir. Türkçe dersi, anlama (okuma - dinleme) ve anlatma (konuşma - yazma) becerilerinin geliştirilmesini amaçlayan bir beceri dersidir. Dolayısıyla ders kitapları da bu becerilerin gelişiminin sağlanmasında etkili olacağı düşünülerek hazırlanmalıdır. Öğrencilerin, öğretim programlarında bulunan kazanımlara ulaşmasında ders kitaplarının önemi büyüktür. Ders kitaplarııı kolay ulaşılabilir bir araç olması, tüm öğrenciler tarafından yaygın olarak kullanılması, metinlerde temaya uygunluğun esas alınması, öğrenci seviyesine uygunluk ve görsellerin çeşitliliği gibi nedenler kitapların önemini göstermektedir (Göçer, 2008).

\section{Öğretmenlerin Ders Kitaplarına Bağlılıkları}

Teknolojinin gelişmesi insan hayatının her alanına yansımış ve kolaylıkları da beraberinde getirmiştir. İnternetin yaygınlaşması bilgiye ulaşmanın yollarını kısaltarak öğrenmenin hızını artırmıştır. Bununla birlikte yazılı kaynak olan ders kitaplarının, eğitim-öğretimde vazgeçilmez olan yerini koruduğunu söylemek de mümkündür. Bu durum onun öğretim programlarının uygulayıcısı olan öğretmenler tarafından hâlâ tercih edilebilir konumda olan öncelikli eğitim araçlarından biri olduğunu göstermektedir. Öztürk'e (2019) göre ders kitaplarına bağılığı etkileyen etmenler şunlardır:

- Öğretmen özellikleri

- Ders kitabının özellikleri

- Öğretmen eğitimi

- Okulların özellikleri

- Çevresel özellikler.

Burada öğretmenlerin eğitim anlayışı, ders kitaplarının işlevselliği, öğretmenlerin fakülte sıralarında aldıkları meslekî eğitim, görev yaptıkları okulların yenilikçi eğitim anlayışına bakış açısı ve okul kültürü ile okulun içinde bulunduğu sosyo-ekonomik kültürel çevre öğretmenlerin ders kitaplarına bağlıı̆ı̆ını genel anlamda etkileyen etmenlerdir.

Öğretmenlerin ders kitabını kullanma amaçlarını şu şekilde sıralamak mümkündür:

- Dersin etkili bir şekilde işlenişini sağlamak

- Sınıf yönetimini sağlamak

- Üniteleri/konuları/temaları/kazanımları yetiştirmek

- Sarmal bir program izlemek

- Aşamalı bir program izlemek

- Ödev vermek

- Farklı sınıf şubeleri arasında işleniş standardı yakalayabilmek

- İdarî bir sorun çıkma ihtimalinin önüne geçmek (Öztürk, 2019).

Türkçe ders kitapları Millî Eğitim Bakanlığı Ders Kitapları ve Eğitim Araçları Yönetmeliği doğrultusunda hazırlanmaktadır. Bu yönetmeliğin amacı:

"Millî Eğitim Bakanlığına bağlı örgün ve yaygın eğitim kurumlarında okutulacak ders kitabı, öğrenci çalışma kitabı, öğretmen kılavuz kitapları ile Bakanlıkça hazırlanacak, satın alınacak veya hibe yoluyla sağlanacak diğer eğitim araç-gereçlerinin Türk millî eğitiminin genel amaç ve temel ilkelerine uygun olarak niteliklerinin belirlenmesi, hazırlanması, hazırlatılması, incelenmesi, inceletilmesi, değerlendirilmesi, kabulü, uygunluk süresi ilanı, yayımlanması, dağıtımı, inceleme ve inceleme ücretleri ve ders kitapları üreten yayınevlerinde aranacak kriterlerle ilgili usul ve esasları düzenlemektir." (MEB, 2012, Birinci bölüm, para. 1).

Türkçe öğretmenleri derslerde, adı geçen yönetmeliğe uygun olarak hazırlanan Türkçe ders kitaplarını kullanmakla yükümlüdürler. 18 Kasım 1982 tarih ve 2709 sayılı Türkiye Cumhuriyeti Anayasanın onuncu maddesinde "Herkes dil, ırk, renk, cinsiyet, siyasi düşünce, felsefi inanç, din, mezhep ve benzeri sebeplerle ayırım gözetilmeksizin kanun önünde eşittir." ibaresi yer almaktadır. Bu eşitlik ilkesine göre hazırlanan ders kitapları Millî Eğitim Bakanlığı tarafından okullara ücretsiz olarak dağıtılmaktadır. Bu nedenle bütün öğretmenler bu ders kitaplarına bağlı kalmak durumundadırlar. 
Türkçe dersi yalnız bilgi aktarımının yapıldığı bir ders değildir. Öğrencinin, hayatının her anında yansımasını bulacağı ve öğrendiklerini anlama-anlatma sahalarında uygulayabileceği bir derstir. Bu açıdan bakıldığında Türkçe öğretmenlerinin ders kitaplarına bağlılıklarını dört temel dil becerisini geliştirmek için etkinliklerden faydalanmak, edebî zevk ve incelik kazandırmak, dil bilgisi eğitimini vermek, metinler aracılığı ile Türkçeyi sevdirmek ve okuma alışkanlığı kazandırmak, kelime hazinesini geliştirmek, ölçme-değerlendirmeyi gerçekleştirmek vb. amaçlar doğrultusunda değerlendirmek gerekir.

Türkçe ders kitapları, Türkçe Öğretim Programı esas alınarak oluşturulan ders araçlarıdır. Dolayısıyla ders kitaplarına olan bağlıık bir başka açıdan bakıldığında ders programına bağlılığın da bir parçasıdır. Bümen vd.'ne (2014: 211-217) göre “öğretim programına bağlılı̆̆ı etkileyen etmenler: Öğretmen özellikleri, program özellikleri, öğretmen eğitimi, kurumsal özellikler, geleceği belirleyici sınavlar ve öğrenci özellikleridir".

Türkçe ders kitapları, ana hatları Türkçe Dersi Öğretim Programı tarafından çizilen ve dört temel dil becerisinin geliştirilmesinin amaçlandığı ders araçlarıdır. Dil bilgisi kazanımları da metinden bağımsız olarak değil, bu kazanımlara uygun metinler ve etkinlikler yoluyla verilmektedir. Akın'a (2015) göre dil bilgisi etkinlikleri önemli bir husustur ve bu etkinlikler mümkün olduğunca ana metinden ve görsel unsurlardan yararlanılarak hazırlanmalıdır. Türkçe derslerinde hedef ve kazanımlara ulaşılmasında metinlerin önemli rolleri vardır, bu nedenle metinler anlaşılır ve okunabilir olmalıdır (Güven, 2014). Türkçe Dersi Öğretim Programı́nda her beceri alanının önemli olduğuna vurgu yapılarak, okuma kültürü ve okuma alışkanlığının kazandırılmasında sorumluluk Türkçe dersine yüklenmiştir. Bu nedenle ders kitabında yer alacak metinlerin nitelikli olması gerekmektedir (İşeri, 2010). Ders işlenişinde öğretmenin en temel aracı ders kitabıdır, bununla öğrencilerin Türkçeye olan ilgilerinin artması ve okuma alışkanlığı kazanabilmeleri amaçlanmaktadır. Bu nedenle hem bu amaçlara hizmet edecek olmasında hem de ders için sağlam bir kaynak olmasında içerik ve görsellik önemlidir.

Bu araştırmanın amacı Türkçe öğretmenlerinin Türkçe ders kitaplarına bağlııklarına yönelik görüşlerini belirlemektir. Özbay'ın (2003) araştırmasına göre Türkçe öğretmenlerinin \%94,44'ü öncelikli olarak ders kitabından yararlanırken, \%5,53'ü dergi, gazete ve diğer görsel-işitsel araçlardan yararlanmaktadır. Gedik, Pesen ve Tekin'in (2016) araştırmasına göre öğretmenlerin \%53'ü ders kitaplarını iyi tanımakta ve intiyaçlarını karşılayabilirken, \%57,1'i ders kitabının yanı sıra farklı kaynaklardan da yararlanmaktadırlar. Epçaçan ve Okçu'nun (2010) ilköğretim Türkçe ders kitaplarına ilişkin öğretmen görüşlerini incelediği araştırmasına katılan dört yüz öğretmenin tamamı Türkçe ders kitaplarının yeterliliği konusunda kararsız olduklarını belirtmişlerdir. Türkçe öğretmenlerinin ders kitaplarına bağılıılarını etkileyen faktörlerin belirlenmesi eğitim öğretimin en temel aracı olan ders kitaplarının hazırlanmasında ve verimli kullanılmasında önemlidir. Öğrenci sıralarına gelene kadar hazırlanma aşamasından denetim ve dağıtım aşamalarına kadar Millî Eğitim Bakanlığının Ders Kitapları ve Eğitim Araçları Yönetmeliği'ne göre belirtilen hususlar doğrultusunda ders kitaplarının üzerinde büyük bir özenle çalışıldığı bilinmektedir. Ancak ders kitaplarına bağlılığı etkileyecek ders kitabı, öğretim programı, öğrenci, öğretmen vb. kaynaklı birtakım aksaklıklar uygulama sırasında öğretmenler tarafından tespit edilecektir. Daha sonraki yıllarda bu aksaklıkların giderilmesinde gerekli adımların atılması için öğretmen görüşleri önemlidir. Bunun yanı sıra bu araştırma, Türkçe öğretmenlerinin ders kitaplarına bağlılıkları konusunda kendilerini değerlendirme olanağı sunması açısından da önemlidir. Bu araştırma ile Türkçe öğretmenlerinin ders kitaplarına ek olarak farklı bir kaynak kullanmaya ihtiyaç duyup duymadıklarını öğrenmek ve intiyaç duymaları durumunda buna neden olan etkenleri belirlemek amaçlanmıştır. Bu araştırmanın benzer araştırmalardan farkı, ders kitaplarının yeterliği veya yetersizliği dışında öğrenci seviyesi ve öğretmen (alan bilgisi ve yaratıcılık) kaynaklı durumların ders kitabından yararlanmayı nasıl etkilediğini ortaya koymak ve bu durumların ders kitabı dışında farklı bir kaynak (kitap, dergi, metin, çalışma kâğıdı vb.) kullanmayı gerektirip gerektirmediğini belirlemektir. 


\section{Araştırmanın Modeli}

\section{Yöntem}

Bu araştırma, Türkçe öğretmenlerinin ders kitabına bağlılıkları üzerindeki görüşlerinin değerlendirildiği nitel bir çalışmadır. Yıldırım ve Şimşek'e (2011: 39) göre “Nitel araştırma, gözlem, görüşme ve doküman analizi gibi nitel veri toplama yöntemlerinin kullanıldığı; algıların ve olayların doğal ortamda gerçekçi ve bütüncül bir yaklaşımla açığa çıkarılmasına yönelik nitel bir sürecin izlendiği araştırmadır". Görüşme nitel araştırma yöntemlerinde en sık kullanılan tekniklerdendir ve en az iki kişi arasında sözlü olarak gerçekleştirilen bir iletişim sürecidir. Görüşme, araştırmada cevabı aranan sorular çerçevesinde ilgili kişilerden veri toplama şeklinde ifade edilebilir. Görüşme, belirli bir araştırma konusu veya bir soru hakkında ayrıntılı bilgilere ulaşılmasını sağlar (Büyüköztürk vd., 2013: 150). Bu çalışmanın desenini nitel araştırma yaklaşımlarından durum çalışması oluşturmaktadır. Durum çalışması, araştırılan bir olguyu kendi çerçevesi içerisinde inceleyen, olgu ve içinde bulunduğu içerik arasındaki sınırların kesin bir şekilde belirli olmadı̆̆ı, birden fazla kanıt veya veri kaynağının bulunduğu durumlarda kullanılan bir araştırma yöntemidir (Yin,1984). Durum çalışması "nasıl" ve "niçin" soruları temelinde, araştırmacının kontrolü dışındaki olgu ve olayları derinliğine incelemesine olanak veren araştırma yöntemidir. Bu sorulara ek olarak "ne" sorusu da durum çalışmalarında gereklidir (Yıldırım ve Şimşek, 2011). Araştırmada Türkçe öğretmenlerinin Türkçe ders kitaplarına bağlılıkları üzerine derinlemesine inceleme yapmak hedeflendiği ve "nasıl", "ne" sorularıyla ders kitaplarının kullanımına yönelik cevaplar arandığı için durum çalışması yöntemi kullanılmıştır.

\section{Araştırma grubu}

Araştırmada seçkisiz olmayan örnekleme yöntemlerinden amaçsal örnekleme yöntemi esas alınmıştır. Amaçsal örnekleme, çalışmanın amacına uygun olarak bilgi açısından zengin durumların seçilerek derinlemesine araştırma yapılmasına imkân tanır. Belli ölçütleri taşıyan veya belli özelliklere sahip olan bir veya birden fazla özel durumlarda çalışılmak istendiğinde tercih edilir (Büyüköztürk vd., 2013). Araştırmanın çalışma grubunu Aksaray ilinde görev yapan Türkçe öğretmenleri oluşturmaktadır. Çalışmada, Aksaray İ Millî Eğitim Müdürlüğüne bağlı altı farklı ortaokulda görev yapan yirmi Türkçe öğretmeni ile görüşülmüştür. Katılımcılar araştırma konusunda bilgilendirilmiş ve kendilerine gönüllü olur formu imzalatılmıştır. Ayrıca araştırma ve yayın etiğine uyulmuştur. Araştırmaya başlamadan önce 20.05.2020 tarihinde Aksaray îl Millî Eğitim Müdürlüğünden 85705372-44-E.7047484 sayılı belge ile izin alınmıştır. Çalışma grubu ile ilgili ayrıntılı bilgiler aşağıdaki tabloda sunulmuştur.

Tablo 1.

Demografik Özellikler

\begin{tabular}{ccc}
\hline & & $f$ \\
\hline \multirow{2}{*}{ Cinsiyet } & Kadın & 11 \\
& Erkek & 9 \\
\hline \multirow{2}{*}{ Mezuniyet Bölümü } & Türkçe Öğretmenliği & 13 \\
& Türk Dili ve Edebiyatı & 6 \\
Görev Süresi & Sınıf Öğretmenliği & 2 \\
& $5-10$ yıl & 1 \\
& $10-15$ yıl & 6 \\
\hline
\end{tabular}

\section{Veri Toplama Aracı}

Araştırmada derinlemesine bilgi elde edebilmek amacıyla yarı yapılandırılmış görüşme formu kullanılmıştır. Görüşme soruları için alan araştırması yapılmış ve Öztürk'ün (2019) yüksek lisans tezi incelenmiştir. İki farklı alan uzmanının da görüşü alınarak 5 açık uçlu sorudan oluşan yarı yapılandırılmış görüşme formu ve iki soru için de sonda hazırlanmıştır. Sonda, görüşülen bireyin 
soruyu daha iyi anlamasına yardımcı olmak ve daha ayrıntılı cevaplar vermesini sağlamak için kullanılır (Yıldırım ve Şimşek, 2011). Kapsam geçerliği için alan uzmanlarının görüşü alınmıştır. Uzman görüşlerine göre "Ders kitaplarına bağlılığınızı azaltan durumlarla karşılaşıyor musunuz? Bunlar nelerdir?" sorusu ile "Derse hazırlık aşaması açısından ders kitabına bağlılığınızı değerlendirir misiniz?" soruları görüşme formundan çıkarılmıştır. Dolayısıyla yedi olan soru sayısı beşe düşürülmüştür. Araştırma öncesinde ön uygulama için beş farklı Türkçe öğretmeniyle görüşülmüş ve görüşme soruları ile görüşme süreci hakkında kendilerinden dönüt alınmıştır. Formun güvenirliği için bu beş öğretmenle yapılan görüşme kayıtlarının tutarlılı̆ına bakılmıştır. Kayıtların çözümlenmesinde yapılabilecek yanlışlıkların en aza indirgenmesi için çözümleme tutarlıı̆ına bakılması gerekmektedir. Bunun için uyuşum yüzdesi formülü " $P=N a \times 100 / N a$ x Nd" (P: Uyuşum yüzdesi, Na: Uyuşum miktarı, Nd: Uyuşmazlık miktarı) kullanılabilir (Croll, 1986; Akt. Türnüklü, 2000). Buna göre ilk kodlamadan üç hafta sonra, beş öğretmenle yapılan görüşmeden alınan kayıtlar araştırmacı tarafından tekrar incelenmiştir. Her iki çözümlemedeki kodlamalar karşılaştırılmış ve uyuşum yüzdesi formülüne göre hesaplanarak uyuşum yüzdesi 0,95 olarak bulunmuştur. Böylelikle alan uzmanlarının da görüşü alınarak hazırlanan formun güvenilir olduğu anlaşılmıştır. Araştırma sürecinde katılımcılara yöneltilen sorular şunlardır:

1. Ders kitaplarında yer alan temalar kapsamında verilen metinler dışında, ders kitabına bağı kalmadan farklı bir metin işleme ihtiyacı duyuyor musunuz? Örnek vererek açıklar mısınız?

2. Ders kitabında yer alan etkinlikler (metin işleme sürecinde ve tema sonu değerlendirmesi) sizin ders kitabına bağlılığınızı nasıl etkiler?

Sonda: Daha farklı türde ölçme değerlendirme etkinliklerine intiyaç duyar mısınız? Örnek vererek açıklar mısınız?

3. Sahip olduğunuz alan bilgisi ders kitaplarına bağlııı̆ınızı nasıl etkiler?

Sonda: Sahip olduğunuz alan bilgisinin yeterli/yetersiz olduğunu düşündüğünüz durumlarda ders kitaplarına ne kadar bağlı kalırsınız?

4. Öğrenci seviyesi ders kitabına bağııı̆̆ınızı nasıl etkiler?

5. Ders kitaplarına bağıııı öğretmenin yaratıcııı̆ını nasıl etkiler?

\section{Verilerin Toplanması}

Araştırmada Aksaray ilı Millî Eğitim Müdürlüğüne bağlı altı farklı ortaokulda görev yapan yirmi Türkçe öğretmeni ile yüz yüze görüşülmüştür. Katılımcılar araştırma konusunda bilgilendirilmiştir. Görüşmeler ses kayıt cihazı ile kayıt altına alınmıştır. Bu kayıtlardan en kısası 3 dakika 49 saniye sürerken en uzunu 18 dakika 42 saniye sürmüştür. Kayıtlar araştırmacı tarafından bilgisayarda yazılmış ve incelemeler bu dokümanlar üzerinde yapılmıştır.

\section{Verilerin Analizi}

Bu çalışma nitel bir araştırmadır ve bunun için nitel araştırma yöntemlerinden içerik analizi yöntemi kullanılmıştır.

İçerik analizi özellikle gözlem ve görüşmelerden elde edilen verilerin analizinde kullanılır (Büyüköztürk vd., 2013). İçerik analizinde temel amaç, toplanan verileri açıklayabilecek kavramlara ve ilişkilere ulaşmaktır. Bu amaçla öncelikle, toplanan verilerin kavramsallaştırılması, daha sonra da ortaya çıkan kavramlara göre mantıklı bir biçimde düzenlenmesi ve buna göre veriyi açıklayan temaların belirlenmesi gerekmektedir (Yıldırım ve Şimşek, 2011).

Kayıt altına alınan görüşmelerin yazıya geçirilmesi sırasında her bir öğretmen için Ö1, Ö2, Ö3... şeklinde kodlar verilmiştir. Görüşme cümlelerinin analizleri sırasında anlamsal açıdan benzerlik gösteren görüşler birleştirilerek kodlar oluşturulmuştur. Temaların oluşturulmasında ise araştırma soruları yol gösterici olmuştur. Kodlar ve temalar düzenlenmiş ve frekans dağılımları yapılmıştır. Temaların güvenirliği için üç ayrı uzman kodlama yapmıştır. Araştırmacı tarafından rastgele seçilen on öğretmenin kayıtlarını Türkçe eğitimi alanında uzman başka iki kişi daha incelemiştir. Daha sonra kodlamalar karşılaştırılarak kodlama benzerlikleri ve farklılıklar değerlendirilmiştir. Miles ve Hubermen'in (2015) uyuşum yüzdesi formülü “Güvenirlik = Görüş birliği sayısı / toplam görüş birliği + 
görüş ayrılığı sayısı" kullanılarak araştırmacı ve uzmanlar arasındaki uyuşum yüzdesi 0,94 olarak bulunmuştur. Böylelikle güvenirliğin yüksek olduğu görülmüştür.

\section{Etik Kurulu İzni}

Çalışmada araştırma ve yayın etiğine uyulmuştur. Katılımcılar araştırma hakkında bilgilendirildikten sonra kendilerine gönüllü olur formu imzalatılmıştır.

Kurul adı= Aksaray ilı Millî Eğitim Müdürlüğü

Kurul Tarihi $=20.05 .2020$

Belge sayı numarası $=85705372-44-E .7047484$

\section{Bulgular}

Araştırmada elde edilen bulgular ulaşılan temalar kapsamında değerlendirilmiştir. Buna göre metin kullanımı, etkinlik, alan bilgisi, öğrenci seviyesi ve öğretmen yaratıcılığı temalarındaki bulgular başlıklandırılarak sunulmuştur.

\section{Metin Kullanımı Temasına İlişkin Bulgular}

Araştırmaya katılan öğretmenlere yöneltilen ilk soru şudur: "Ders kitaplarında yer alan temalar kapsamında verilen metinler dışında, ders kitabına bağlı kalmadan farklı bir metin işleme ihtiyacı duyuyor musunuz? Örnek vererek açıklar mısınız?" sorusudur. "Metin kullanımı" teması kapsamında verilen cevaplardan yedi kod tespit edilmiştir. Kodlar ve bunlara bağlı olarak belirlenen frekanslara aşağıdaki tabloda yer verilmiştir.

Tablo 2.

Metin Kullanımı Temasına Iliş̧kin Kod ve Frekans Dağılımı

\begin{tabular}{cll}
\hline Tema & Kod & $f$ \\
\hline & Ders kitabının yeterli görülmesi & 9 \\
& Öğrenci seviyesine uygunluk & 6 \\
& Metin çeşitliliğini sağlamak & 3 \\
Metin Kullanımı & Kazanımlara uygunluk & 2 \\
& Etkinliklerin ders kitabındaki metnin işlenişini gerekli kılması & 1 \\
& Derse hazırık sürecinde farklı bir metne ihtiyaç duyulması & 1 \\
& Metnin öğrenciye hitap etmemesi & 1 \\
\hline
\end{tabular}

Katılımcıların tamamı ders kitaplarındaki metinlere bağlı kaldıklarını ancak çeşitli nedenlerle kitap dışından farklı metinler de kullanabildiklerini belirtmişlerdir. Verilen cevaplara göre yirmi öğretmenden dokuzunun ders kitaplarındaki metinler dışında farklı bir kaynaktan metin kullanmadıkları görülmüştür. Bununla ilgili olarak verilen cevaplarından bazıları şunlardır:

"Ben ders kitapları dışında başka kaynaklardan ders işlemiyorum. Ders kitaplarına bağlıyım. O yüzden şimdiye kadar farklı bir metin getirmedim." (Ö4),

"Farklı bir metin işlemiyorum, ders kitabına bağlı kalıyorum." (Ö8),

"Ünitelerdeki metinleri ben yeterli buluyorum... Metinler seviyeye uygun bana göre. Yani kapalı metin yok, ortaokul seviyesine uygun... Daha da önemlisi insanı sıkmayan metinler, yani ben ayrı bir gereksinim duymuyorum bu konuda" (Ö13).

Araştırmada yapılan incelemelerde altı öğretmenin, Türkçe ders kitaplarında yer alan metinleri öğrenci seviyesine uygun bulmadıkları durumlarda faklı bir kaynaktan metin kullanabildiklerini ifade ettiği belirlenmiştir. Öğretmenlerden bazılarının görüşlerine aşağıda yer verilmiştir:

"Evet duyuyorum. Çünkü metinlerin öğrencilerin seviyesine uygun olmadığını düşünüyorum. Çoğu zaman cümleleri anlamadıklarını, paragraftaki anlama düzeylerinin düşük olduğunu görüyorum. 
Bunun için onların anlayabileceği bir şekilde daha çok hikâye türünde metinlerden yararlanıyorum." (Ö1),

"Bazı metinler sınıf seviyelerine uygun değil diye düşünüyorum. Metinler sınıf seviyesinin üstünde ya da altında kalabiliyor... Bu yüzden yeri geliyor ders kitabına bağlı kalamıyorum doğru söylemek gerekirse." (Ö2),

"Öğrenci seviyesine uygun olmadığını düşündüğg̈m durumlarda farklı metin kullanma ihtiyacı duyuyorum." (Ö14).

Metin kullanımı temasında sık kullanılan kodlamalardan birisi de "Metin çeşitliliğini sağlamak"tır. Bununla ilgili olarak 3 öğretmen farklı metin kullanma ihtiyacı duyduğunu belirtmektedir. Ö12'nin "Genel anlamda ders kitaplarındaki metinler bana yetiyor ama zaman zaman da ihtiyaç duyuyorum evet... Mesela geçtiğimiz hafta iyilik üzerine bir metin okuduk, buna binaen Yunus Emre'den bir şiir okudum" ve Ö3'ün "Duyuyoruz. Şöyle ki, yani tek metin her zaman öğrenci için yeterli olmuyor. Birden fazla metin çocuğun hem hayal dünyasını geliştirmesi açısından hem de kendini ifade etmesi, konuyu rahat anlaması açısından güzel oluyor." görüşleri örnek verilebilir.

Tablo 2'de görüldüğü gibi "Kazanımlara uygunluk" kodlaması için iki öğretmen Türkçe ders kitabında yer alan metinlerin hedeflenen kazanımlara uygun olduklarını düşündüklerinden herhangi bir farklı kaynaktan metin işleme ihtiyacı duymadıklarını belirtmişlerdir. Ayrıca bir öğretmen (Ö6) "Etkinliklerin ders kitabındaki metnin işlenişini gerekli kılması" koduyla ilgili olarak etkinliklerin metinlere bağı olarak hazırlanması nedeniyle ders kitabı dışında farklı bir kaynaktan metin işlemediğini ifade etmiştir. Aynı öğretmen "Derse hazırlık sürecinde farklı bir metne ihtiyaç duyulması" koduyla ilişkili olarak derse hazırlık sürecinde bazen farklı metinler kullanarak öğrencileri güdülediğinden söz etmiştir. Bunlar dışında Ö10'un “Öğrencilerimizin bireysel durumları, zekâ yapıları, bölgesel, kültürel, ahlâkî değerler, iklim şartları gibi nedenler farklı metin ihtiyacı duymamızı ve kullanmamıza neden oluyor." düşüncesi, "Metnin öğrenciye hitap etmemesi" koduna örnek olarak gösterilebilir.

\section{Etkinlik Temasına İlişkin Bulgular}

Ders kitaplarında yer alan etkinlikler bağlamında araştırmaya katılan öğretmenlere "Ders kitabında yer alan etkinlikler sizin kitaba bağlılığınızı nasıl etkiler?" sorusu yöneltilmiştir. Verilen cevaplar üzerinde yapılan içerik analizi sonunda on bir kod tespit edilmiştir. Diğer sorularda da olduğu gibi bazı katılımcıların birden fazla kodu kapsayacak cevaplar verdikleri görülmüştür. Örneğin Ö2, dört kod ile ilişkilendirilecek cevaplar vermiştir. Kodlar ve bunlara bağı frekanslara ait bilgiler aşağıdaki tabloda bulunmaktadır.

Tablo 3.

Etkinlik Temasına ilişskin Kod ve Frekans Dağılımı

\begin{tabular}{lll}
\hline Tema & Kod & $f$ \\
\hline & Etkinliklerin yetersiz kalması & 8 \\
& Konunun pekişmesini sağlamak & 4 \\
& Öğrencileri merkezî sınavlara hazırlama intiyacı & 4 \\
& Bazı etkinliklerin fazlalık olduğunun düşünülmesi & 3 \\
& Tema sonu değerlendirmelerinin etkili olması & 3 \\
& Öğrenci seviyesine uygunluk & 2 \\
& Soru çeşidini artırmak & 2 \\
& Ders kitabındaki etkinliklerin yeterli görülmesi & 2 \\
& Konunun anlaşılmasına destek olmak & 2 \\
& Etkinliklerde rutinin dışına çıkmak & 1 \\
& Sınıf kademesi & 1 \\
\hline
\end{tabular}


Yukarıdaki tabloda görüldüğü gibi en yoğun frekans (8), "Etkinliklerin yetersiz kalması" koduna bağlıdır. Yani 8 öğretmen etkinlikleri yetersiz gördüklerinden ders dışında farklı kaynaklardan etkinlik temin etmektedir. Kayıtlardan öğretmenlerin etkinlik sayılarının yetersiz olduğunu düşündükleri anlaşılmıştır. Aşağıda bazı öğretmenlerin adı geçen kodu destekleyecek görüşlerine yer verilmiştir:

"Verilen etkinlikler bazen yetersiz kalıyor, çocuğun anlamasını engelliyor. Bu tarz durumlarda çocuğa yardımcı olmak açısından farklı etkinlikler uyguluyorum" (Ö3),

"Etkinlikler açısından kitap yetersiz kalıyor. Yani özellikle dil bilgisi konusuysa çocuklar tamamen eksik kalıyorlar. O yüzden mecburen kitap dışına çıkmam gerekiyor." (Ö5),

"Açıkçası ben dil bilgisi alanında ders kitabındaki etkinlikleri çok fazla yeterli bulmuyorum. $O$ yüzden bazen ders kitabının dışına çıkıp farklı kaynaklardan yararlandığım oluyor" (Ö6).

Araştırmada elde edilen bir başka bulgu, dört öğretmenin "Konuların pekişmesini sağlamak" amacıyla etkinliklere bağlı kalmakla birlikte farklı ölçme değerlendirme etkinliklerine de ihtiyaç duymalarıdır. Örneğin Ö4'ün "Türkçe ders kitabına bağlıyım, sadece ara sıra çocuklar konuyu pekiştirsin diye test getiriyorum, onları çözüyorlar." ifadesi ve Ö11'in "Genellikle ders kitabına bağlıyımdır. Onun haricinde metin işleme sürecinde yeri geldiğince akıllı tahtadan ve diğer ek kaynaklardan yararlanarak konuyu daha da pekiştirme yoluna giderim." görüşü adı geçen kodu açıklayıcı niteliktedir.

Araştırmada öğretmenlerin etkinlikler bağlamında Türkçe ders kitaplarına bağlılıklarıyla ilgili olarak dört öğretmenin görüşleri doğrultusunda "Öğrencileri merkezî sınavlara hazırlamak" kodu tespit edilmiştir. Bu öğretmenler ders kitaplarındaki etkinliklere bağlı kaldıklarını ancak öğrencilerin merkezî sınavlara hazırlanabilmesi için faklı ölçme değerlendirme etkinliklerini de kullandıklarını belirtmişlerdir. İlgili kod bağlamında Ö12 "Genel anlamda ders kitaplarındaki etkinliklere bağlıyım. Çoktan seçmeli sorulara ihtiyaç duyuyorum. Çünkü günümüzde ölçme değerlendirmede çoktan seçmeli sorular çok fazla kullanıldığından, lise yerleştirme sınavlarında bu tür sorulara yer verildiği için çocukları çoktan seçmeli soru tekniğine alıştırmak adına başvuruyorum." görüşü örnek verilebilir. Ayrıca yine bu doğrultuda Ö17 "Kendimi öğrencilerin girmek zorunda oldukları sınava uygun nitelikli çoktan seçmeli sorularla tanıştırmak zorunda hissediyorum." ifadesi de "Öğrencileri merkezî sınavlara hazırlamak" kodunu destekler niteliktedir.

Etkinlikler bağlamında ders kitaplarının kullanımı ile ilgili olarak üç öğretmen bazı etkinliklerin gereksiz olduğunu düşündüklerinden bu tür etkinliklerde Türkçe ders kitabına bağıı kalmadıklarını belirtmişlerdir. Ö7'nin "Metin işleme sürecinde verilen etkinliklerin tamamını kullanmıyorum. Çünkü bazı etkinlikler çok gereksiz. Bazılarını okumaya bile gerek olmuyor. Eğer dil bilgisi etkinliği varsa çocuklarla o dil bilgisi etkinliğini tamamen bitiriyoruz ama okuma anlama adı altındaki etkinliklerin tamamını yapma gereği duymuyoruz" görüşü öğretmenin dil bilgisi etkinliklerine öncelik verdiğini göstermektedir. Ö20'nin "faydalı olmayacağını düşündüğüm bazı etkinlikleri yaptırmıyorum. Kesinlikle farklı türde ölçme değerlendirme tekniklerine ihtiyaç duyuyorum." görüşü etkinliklerin fazlalığı ile ilgili kodlamaya örnek verilebilir.

Araştırmaya katılan üç öğretmen, tema sonu değerlendirmelerinin öğrenmede etkili olduğunu düşündüklerinden ders kitaplarına bağıı kaldıklarını belirtmişlerdir. Bununla ilgili olarak Ö2, "Her temanın sonundaki tema değerlendirme etkinliklerini mutlaka yaptırırım. Çünkü benim anlattığım konularla bağlantılı olduğu için öğrenci neyi ne kadar aldı, bunu tema sonu çalışmalarla görebiliyoruz." görüşünü belirtmiştir. Ö19 da "Tema değerlendirmelerini de faydalı bulduğum için derste yaptırıyorum. Bu anlamda ders kitabını mutlaka takip ederim." şeklinde görüş bildirmiştir.

"Öğrenci seviyesine uygunluk" koduyla ilgili olarak iki öğretmen etkinlikler bağlamında ders kitabına bağlılıklarını değerlendirmişlerdir. Buna göre her ikisi de ders kitaplarına bağlı kalmışlar ancak etkinliklerin öğrenci seviyesine uygun olmadığı durumlarda kitap dışına çıkabildiklerini ifade etmişlerdir. Bununla ilgili olarak öğretmenlerin görüşleri şunlardır:

"Yani ben oradaki etkinliklerin öğrencilere yararlı olmadığını gördügü̈mde farklı etkinlikler yapmak istiyorum ve bunu yapıyorum. O zaman anlayabilecekleri türde farklı etkinliklere yöneliyorum. Ders kitabı dışındaki etkinlikleri de kullanıyorum." (Ö1), 
"Ders kitabındaki etkinlikleri yapıyoruz, bunlar dışında kendim de ek etkinlikler yaptırıyorum ögrrencilere. Anlama hızları farklı öğrenciler bulunduğu için sınıfta çeşitli ek etkinlikler uygulatıyorum onlara." (Ö16).

"Soru çeşidini artırmak" koduyla ilgili olarak iki öğretmen görüş belirtmiştir. Ö18'in "Araştırma sorularını mutlaka öğrencilere ödev veriyorum. Ders kitabı dışında mutlaka farklı kaynaklardan soru çözümü yaparım. Testlerden faydalanırım." görüşü ilgili koda örnek gösterilebilir. Yapılan incelemelerde öğretmenlerin etkinlik bağlamında önceliklerinin ders kitabı olduğu ve soru çeşitliliği sağlamak için kitap dışına çıkabildikleri belirlenmiştir.

"Ders kitabındaki etkinliklerin yeterli görülmesi" kodu iki öğretmenin görüşleri doğrultusunda oluşturulmuştur. Bununla ilgili olarak Ö13'ün, "Tema değerlendirme sorularına baktığım zaman orada farklı bir soru görmüyorum. Yani metinlerde, etkinliklerde ne varsa onlarla bağlantılı. Yani oradaki sorular da metinle paralel ve faydalı sorular var. Ben ders kitabı dışında bir etkinliğe ihtiyaç duymuyorum, okul saatinde müfredatı uyguluyorum, ders kitabını kullanıyorum." görüşü öğretmenin ders kitabında bulunan etkinlikleri yeterli gördügünü göstermektedir.

Araştırmaya katılan iki öğretmenin görüşlerinden yola çıkılarak "Konunun anlaşılmasına destek olmak" kodu ortaya çıkmıştır. Buna göre onlar etkinliklerde ders kitaplarına bağlı kalmakla birlikte öğrencilerin, konuyu tam olarak anlayamamaları durumunda farklı kaynaklardan yararlanmaktadırlar. Bunun dışında bir öğretmen, etkinliklerde rutinin dışına çıkmak için farklı kaynaklarda etkinliklere yer vermekte (Ö1), bir öğretmen de etkinliklere bağlılı̆ını sınıf kademesi ile ilişkilendirmektedir. Ö7 bununla ilgili olarak şunları belirtmiştir:

"Girdiğim sınıflarda daha çok 5., 6. ve 7. sınıflarda ders kitabına bağlıık söz konusu. Ama 8. sınıf çocukları LGS'ye girecekleri için ders kitabına çok bağılıktan ziyade akıllı tahtayı kullanmakla birlikte örnek sorular veya herhangi bir test, ünite sonu değerlendirme, EBA'dan veya diğer interaktif eğitim platformlarından yararlanıyorum." Burada öğretmenin 8. sınıf seviyesinde merkezî sınav nedeniyle ders kitabı kullanımını esnettiğini, kitap dışındaki kaynaklara öncelik verdiği görülmektedir. Sınava hazırlık kaygısının olmadığı diğer sınıf seviyelerinde ise tamamen ders kitabını kullanmaktadır.

Birer frekansa sahip olan "Etkinliklerde rutinin dışına çıkmak" kodu ile eğitim verilen sınıf kademesi (5., 6., 7. ve 8. sınıf) de kitaba bağlılıklarını esneten durumlar olarak görülmektedir .

\section{Alan Bilgisi Temasına İlişkin Bulgular}

Türkçe öğretmenlerinin ders kitaplarına bağlılığı üzerine yapılan araştırmada öğretmenlere yöneltilen bir başka soru, "Sahip olduğunuz alan bilgisi ders kitabına bağlılı̆ınızı nasıl etkiler?" sorusudur. Öğretmenlerin verdikleri cevaplar incelendiğinde "Alan bilgisi" temasına bağlı olarak dokuz kod belirlenmiştir ve bulgular aşağıdaki tabloda frekanslarıyla birlikte sunulmuştur.

Tablo 4.

Alan Bilgisi Temasına iliş̧kin Kod ve Frekans Dağılımı

\begin{tabular}{clc}
\hline Tema & Kod & $f$ \\
\hline & Ders kitabının öğretmenin alan bilgisini destekleyici & 15 \\
& nitelikte olmaması & \\
& Alan bilgisinde farklı kaynaklardan yararlanma ihtiyacı & 7 \\
& Öğretmenin kendi alan bilgisine güvenmesi & 4 \\
& Ders kitaplarındaki bilgilerin güncelliği & 2 \\
Alan Bilgisi & Öğretmenin meslekî tecrübesi & 2 \\
& Öğretmenin bilgisini tazeleme ihtiyacı & 2 \\
& Tartışmalı konuların kitaba bağlılı̆ı̆ gerektirmesi & 1 \\
& Sınıf kademesi & 1 \\
& Ders kitaplarının yeterli görülmesi & 1 \\
\hline
\end{tabular}


Alan bilgisi temasına bağlı olarak öğretmenlerin verdikleri cevaplardan yola çıkılarak oluşturulan kodlar içinde en yoğun frekansa (15) sahip olan kod "Ders kitabının öğretmenin alan bilgisini destekleyici nitelikte olmaması"dır. Yani araştırmaya katılan yirmi öğretmenden on beşi Türkçe ders kitaplarında alan bilgisi açısından öğretmeni destekleyici unsur bulunmadığını düşünmeleri onların kitaba bağlılığını etkilemektedir. Katılımcılardan birkaçının konuyla ilgili görüşleri şunlardır:

"Bizim ders kitaplarımızda genel olarak etkinlikler var, konuları anlatmıyor. O yüzden öncesinde ders kitabında hangi konu var ona bakıyorum. Evde hazırlanıp konuyu anlatıyorum. Ders kitabından da etkinliği yapıyoruz." (Ö4),

"Dil bilgisi etkinliklerine çok az yer veriliyor. Ben bu yüzden kendi alan bilgimi kullanarak ekstradan farklı kaynaklardan yararlanarak çocuklara dil bilgisi konuları üzerinde duruyor ve buna göre de ders saatimin belli bir kısmını ayırıyorum. O sırada ders kitabının dışına çıkıyorum. Ders kitabını alan bilgim için kesinlikle destekleyici olarak düşünmüyorum." (Ö6),

"Sahip olduğum alan bilgisi 8. sınıflarda belki birazcık etkiler dil bilgisi konularında. Yani ekstra dil bilgisi işlemek zorunda kalırım." (Ö9),

"Ben ders kitaplarının alan bilgisinin yeterli olmadığını düşünüyorum. Ders kitaplarını sadece etkinlik çeşitliliği amacıyla kullanıyorum. Alan bilgisi açısından ders kitabının çok da bağlayıcı olduğunu düşünmüyorum." (Ö10),

"Ben alan bilgisi konusunda ders kitaplarının, onlara bağıılığımı etkilediğini düşünmüyorum. Çünkü ders kitaplarında ekstra bana yardımcı olacak bir kılavuz kitap değil. Dolayısıyla ders kitabı benim alan bilgime bir yardımda bulunmuyor." (Ö14).

"Ders kitabına her durumda bağlıyımdır, birçok etkinliği yaparım fakat dil bilgisi konu anlatımı konusunda ya da soru kaynağı olarak mutlaka farklı kaynaklara da başvururum." (Ö20).

Katılımcıların alan bilgisi bağlamında ders kitaplarına bağılıkları ile ilgili olarak verdikleri cevaplarda ders kitaplarına bağlı oldukları ancak özellikle dil bilgisi konularında Ö6, Ö9 ve Ö20'nin ders kitabını yetersiz gördüklerinden farklı kaynaklardan yararlandıkları görülmektedir.

Araştırmaya katılan öğretmenlerin alan bilgisinde farklı kaynaklardan yararlanma ihtiyacı onların ders kitaplarına bağlılığını etkilemektedir. Bu kodla ilgili olarak yedi öğretmenin ortak görüşü olduğu belirlenmiştir. Bunlardan bazıları şunlardır:

"Konu bütünlüğünü bozmadan, bir şeyler gözden kaçmasın diye konuyla ilgili mutlaka kaynaklara göz atıyorum." (Ö1),

"Ders kitaplarını yine ölçü alırım ama onların alan bilgime destekleyici olduğunu düşünmüyorum, diğer ek kaynakları kullanıyorum." (Ö11).

"Öğretmenin kendi alan bilgisine güvenmesi" kodu ile ilgili olarak dört öğretmen görüş bildirmiştir. Buna göre katılımcıların kendi alan bilgilerine olan güvenleri onların ders kitaplarına bağlılıklarını da etkilemektedir. Ö12'nin "Ders kitaplarında verilen bilgi çocuklarda çok soyut kalıyor. Bu anlamda kendi alan bilgimi daha çok kullanıyorum.", Ö13'ün "Ben Türk Dili ve Edebiyatı bölümü mezunuyum. Dolayısıyla bizim okuduğumuz romanlar, öyküler bizim artı özelliklerimiz oluyor. Birikim olarak bakıldığı zaman iki dakikalık bir konuyu biz 80 dakikaya yayabiliyoruz, ders kitabına bağlı kalmadan." ve Ö16'nın "Ders işlenişinde ders kitabına bağlıyım ama alan bilgime güvenirim ve bu konuda ders kitabına sonuna kadar bağlı değilim." görüşleri örnek olarak gösterilebilir. Bu görüşler, onların alan bilgilerine duydukları güven sebebiyle ders kitaplarına olan bağılıklarını ifade eden cümlelerdir. Bunlardan hareketle öğretmenlerin kendi alan bilgilerine güvendiklerinden dolayı ders kitaplarına çok bağlı kalmadıklarını söylemek mümkündür. Bir başka deyişle öğretmenler ders kitabına bağlı olmakla birlikte alan bilgisi söz konusu olduğunda kendi birikimlerini kitaba bağlı kalmak mecburiyeti duymadan rahatlıkla kullanabilmektedirler.

Alan bilgisi teması kapsamında belirlenen diğer bir kod, "öğretmenin meslekî tecrübesi"dir. Bu kodun oluşmasında iki öğretmenin görüşleri etkili olmuştur. Ö7'nin temayla ilgili görüşleri şunlardır:

"Bir öğretmen mesleğe başladığı zaman alan bilgisi olarak 1-5 yıl, 5-10 yıl, 10-15 yıl çok fark ediyor, tecrübe olarak da çok fark ediyor. 1-5 yıl arasında çalışan kitaba daha çok bağlı kalıyor. Çünkü 
kitap onun için çok büyük bir dayanak teşkil ediyor. Ama meslekte yıllar geçtikçe artık kitaptaki verilenlerin haricinde 'Ben daha farklı ne yapabilirim?' gibisinden alan bilgisi burada devreye giriyor."

Ö8 de meslekî tecrübe kodu ile ilgili olarak, "Öğretmenliğe başladığımız yıllarda genellikle ders kitaplarına daha fazla bağlı kalıyorduk. Ders kitapları dışında pek fazla yayın takip etmiyorduk. Ama ilerleyen zamanlarda hem öğrencilerin niteliklerini öğrenmeye başladıkça, hem de dersle ilgili bir şeyler öğrenmeye başladıkça değişik ve güncel örnekler vererek öğrencilerin derse olan ilgisini artırmaya çalışıyoruz." şeklinde düşüncelerini belirtmiştir. Buna göre her iki katılımcının cevaplarından öğretmenin meslekteki tecrübesi arttıkça alan bilgisi bağlamında ders kitabını kullanmada esnekliğin olduğu görülmektedir. Yani onlara göre tecrübe, kitaba bağlılıkta etkili bir faktördür.

Öğretmenlerin alan bilgisi bağlamında iki katılımcının, ders kitabına bağılıılarını anlatan görüşlerinde ortaya çıkan diğer bir kod, öğretmenin bilgisini tazeleme ihtiyacıdır. Ö1'in "Zaman zaman kendimi yenilemek adına farklı kaynaklara hemen başvurarak o konuyu biraz da önceden hazırlık yaparak 'Öğrencilere ne verebilirim, ne kadar verebilirim?' diye kendime sormak faydalı oluyor. Onun için ders kitabı dısında bir kaynak mutlaka kullanıyorum." Görüşlerinden, öğretmenin bilgisini yenileme ihtiyacı duyduğu anlaşılmaktadır.

"Ders kitaplarındaki bilgilerin güncelliği" kodu ile ilgili olarak iki öğretmen görüş bildirmiştir. Ö5' in "Mesela birçok değişiklik oluyor, ders kitapları da güncelleri aldığı için, noktalama işaretlerinde oluyor, yazım kurallarında oluyor mesela. Onlar da bir nevi bizi yenilemiş oluyor mesela." görüşü ve Ö15'in "Türkçede zaman zaman güncellenen bazı konular olduğu için ders kitaplarına başvurabiliyorum." görüşü bu kodu destekler niteliktedir. Ders kitaplarında güncel bilgilerin yer alması dolayısıyla öğretmenlerin alan bilgisi açısından kitaba bağlı kaldıkları ve ondan faydalandıkları belirlenmiştir.

Alan bilgisi teması kapsamında birer frekansa sahip olan "Tartışmalı konuların kitaba bağlıı̆̆ı gerektirmesi (yazım kuralları)", "Öğrenci seviyesine uygunluk", "Sınıf kademesi" ve "Ders kitaplarının yeterli görülmesi" kodları kitaba bağlılıkta belirtilen görüşlerden biridir.

\section{Öğrenci Seviyesi Temasına ilişkin Bulgular}

Türkçe öğretmenlerinin ders kitaplarına bağlılıklarıyla ilgili olarak yapılan araştırmada katıımcılara yöneltilen bir diğer soru, "Öğrenci seviyesi ders kitabına bağlılı̆ınızı nasıl etkiler?" sorusudur. Öğretmenlerin verdikleri cevaplar üzerinde yapılan incelemelerde "Öğrenci seviyesi" teması kapsamında altı kod belirlenmiştir. Bu kodlar ve frekanslarla ilgili bilgiler aşağıdaki tabloda sunulmuştur.

Tablo 5.

Öğrenci Seviyesi Temasına iliş̧kin Kod ve Frekans Dağıımı

\begin{tabular}{clc}
\hline Tema & Kod & $f$ \\
\hline & Akademik başarısı yüksek öğrencilere uygun etkinlik ihtiyacı & 11 \\
& Konunun anlaşılmasını sağlama gayreti & 10 \\
& Öğrenci seviyesine uygun etkinlik sağlama & 2 \\
& Ders̆ içeriğini öğrencinin seviyesine uyarlama & 2 \\
& Öğrencilerin hazır bulunuşluk düzeyine uygunluk & 1 \\
& Araştırma yaptırma & 1 \\
\hline
\end{tabular}

Araştırmada belirlenen bir diğer kod "Akademik başarısı yüksek öğrencilere uygun etkinlik ihtiyacı"dır. Bununla ilgili olarak 11 öğretmen görüş bildirmiştir. Bu görüşlerden bazıları şunlardır:

"Öğrencinin seviyesi kitaba bağlıı̆̆ı çok etkiliyor. Öğrencinin seviyesi yüksekse ders kitabını belki de \%20 düşünebilirsiniz. \%20'den sonraki kısımda farklı çalışmalar yapıyoruz. Hikâye tamamlama, hikâye yazma, şiir yazma, test çözme, deneme yazma... farklı aktiviteler oluyor." (Ö3), 
"Öğrenci seviyesi doğrudan etkiler. Seviye iyiyse eğer kitap bize yetmiyor." (Ö2),

"Öğrenci seviyesi yüksek bir sınıfsa ders kitabı gerçekten çok yetersiz kalıyor. Ben konuyla ilgili başka kaynaklara yöneliyorum, internetten bakıyorum ya da çıktı alıyorum." (Ö5),

"Sınıfın düzeyi yüksekse örneğin tema içerisinde dört tane etkinlik vermişler, ben bu etkinlikleri artırabiliyorum. Sadece dört tane etkinlikle sınırlı kalmıyoruz. Akılı tahta ve farklı kaynaklarla içeriği zenginleştiriyorum." (Ö7),

"Sınıfın seviyesi yüksekse ders kitabı dışında mutlaka farklı etkinlikler yaptığımız oluyor. Öğrenci seviyesinin altında eğitim verirsek öğrenci dersten kopar." (Ö16).

Yukarıdaki örnekler öğretmenlerin, akademik başarısı yüksek sınıflarda ders kitabına bağıı kalmalarının yeterli olmadığını, ders kitabı dışında farklı kaynakları da kullandıklarını göstermektedir.

Öğrenci seviyesinin öğretmenlerin ders kitaplarına bağıııktaki etkisiyle ilgili olarak sorulan soruya verilen cevaplardan en fazla frekansa sahip kodlardan biri olan "Konunun anlaşılmasını sağlama gayreti"dir ve frekansı da $10^{\prime}$ dur. Öğrenci seviyesi bağlamında ders kitabına bağlııklarını ifade eden öğretmenlerin bazılarının görüşleri şunlardır:

“Öğrenci seviyesi ders kitabına bağlıı̆ı̆mı \%100 etkiler. Çünkü benim yapabileceklerim öğrencilerin ne kadar yaptıklarıyla çok ilgili. Öğrencinin yapamadığını görüyorum ve bunun için kitaba bağıı kalıyorum veya kitap dışına çıkabiliyorum." (Ö1),

"Seviyesi düşük olan sınıflarda öğrencinin ilgisini çekmek için ders kitaplarına bağlı kalıyorum. Seviye mutlaka bunu etkiliyor." (Ö8),

"Seviyesi düşük olan sınıflarda da kitaba bağlıyım ama süreç uzuyor sadece." (Ö9).

"Öğrenci seviyesi ders kitabına bağlıı̆̆ımı etkiler. Eğer sınıfın seviyesi düşük ise zaten metni bitirmek zaman alıyor. Farklı bir etkinliğe zaman ayıramıyorum." (Ö18).

Yukarıdaki örneklerde görüldüğü gibi sınıfın başarı düzeyinin düşük olması öğretmeni ders kitabına daha çok bağlayan bir etken olarak görülmektedir. Öğretmen, ders kitabına bağlı kalarak ve ders süresini de konunun anlaşılmasını sağlayacak şekilde ayarlayarak dersi yönetmektedir.

Araştırmada öğrenci seviyesi teması kapsamında tespit edilen kodlardan biri "Öğrenci seviyesine uygun etkinlik sağlama"dır. Bununla ilgili olarak iki öğretmen düşüncesini anlatmıştır. Ö10'un "Yüksek seviyeli öğrencilerin zihinlerini daha fazla yoracak, düşünmeye sevk edecek, farklı ürün oluşturmaya yönelik etkinlikler veriyorum. Daha düşük seviyeli öğrenciler için de daha basit daha temel etkinlikleri yapabilmeleri için etkinlikler düzenliyorum. Ders kitabı dışında kendim de katıyorum." görüşü ile Ö20'nin "Seviyeye uygun bulmadığım etkinlikleri yaptırmam sadece. Öğrenci seviyelerine uygun olan başka kaynaklara (metin, etkinlik vs.) başvururum." görüşü "Öğrenci seviyesine uygun etkinlik sağlama" kodunun oluşmasını sağlamıştır.

"Ders içeriğini öğrencinin seviyesine uyarlama" koduna ilişkin iki öğretmen görüş bildirmiştir. Ö13 bu kodla ilgili olarak "Ben kitaba bağlıyım benim rehberim kitap. O bana yol gösteriyor. Diyelim ki etkinlikte kapalı bir durum var veya fazla etkinlik var. Ben bunu onların seviyesine uygun hale getirerek somut bir halde kavramlarını sağlıyorum. Ama seviye iyiyse zaten onu anladıklarından dolayı öyle bir gereksinim duymuyorum." şeklinde görüş belirtirken, Ö14 "Yani ders kitabında o metin verildiyse o metni işliyoruz. Sadece anlatım yöntemimi, vereceğim örnekleri ya da değiştiriyorum. Ders kitabına bağlıyım yani." görüşleri ilgili kodun temelini oluşturur.

Öğrenci seviyesi teması kapsamında birer frekansa sahip olan "Öğrencilerin hazır bulunuşluk düzeyine uygunluk" ve "Araştırma yaptırma" kodları öğretmenlerin belirttikleri görüşlerden yola çıkılarak oluşturulmuş diğer kodlardır.

\section{Öğretmen Yaratıcılığı Temasına illişkin Bulgular}

Türkçe öğretmenlerinin ders kitaplarına bağlııklarının araştırıldığı çalışmada katılımcılara yöneltilen son soru, "Ders kitaplarına bağlılık öğretmenin yaratıcılı̆̆ını nasıl etkiler?" sorusudur. Bu bağlamda oluşturulan öğretmen yaratıcılığı teması kapsamında sekiz kod belirlenmiştir. Bu kodlar ve kodlara ilişkin frekans dağılımı aşağıdaki tabloda verilmiştir. 
Tablo 6.

Öğretmen Yaratıcılığı Temasına Ilişkin Kod ve Frekans Dağılımı

\begin{tabular}{clc}
\hline Tema & Kod & $f$ \\
\hline & Yaratıcılığı olumsuz etkileme & 13 \\
& Hazırcılığa sebep olma & 3 \\
& Yaratıcılığı etkilememe & 2 \\
\cline { 2 - 2 } Öğretmen Yaratııı̆ığı & Sıradanlaştırma & 1 \\
& Süreci kontrol altında tutma isteği & 1 \\
& Üretkenliğin düşmesi & 1 \\
& Ders kitaplarının ilgi çekmedeki yetersizliği & 1 \\
& Ders kitabının niteliği & 1 \\
\hline
\end{tabular}

Yukarıdaki tabloda görüldüğü gibi en yoğun frekansa (13) sahip olan kod, "Yaratıcılığı olumsuz etkileme" kodudur. Bu bağlamda beş öğretmen ders kitabına tamamen bağlı kalmanın yaratıcılığı körelterek, iki öğretmen sınırlandırarak olumsuz etkilediğini belirtirken 6 öğretmen de sadece olumsuz etkilediğinden söz etmişlerdir. Bu kodla ilgili olarak belirtilen görüşlerden bazıları şunlardır:

"Öğretmen ders kitabına tamamen bağlı kalırsa ders rutinlerin dışına çıkamaz. Yani zaten kitaptaki soru tipleri ve etkinlikler genelde hep aynı şeyler. Bağlı kalırsak bizim yaratıcılığımızı baya düşürüyor." (Ö1),

"Ders kitaplarına bağlılık yaratıcılığı sınırlandırıyor bence." (Ö7),

"Eğer öğretmen tamamen ders kitabına bağı kalırsa yaratıcılığını daraltır çünkü o ders kitabını hazırlayan kişinin bakış açısıyla bakar." (Ö10),

"Ben bu konuda öğretmenin yaratıcılığını olumsuz etkileyeceğini düşünüyorum çünkü ders kitaplarına tamamen bağlı kalırsak kendi bilgi birikimimizi tam özgür bir şekilde verebileceğimizi düşünmüyorum." (Ö12),

"Ben yaratıcılığı olumsuz yönde etkilediğini düşünüyorum. Çünkü müfredata uymak zorundayız. Buna uymak zorunda kaldığım için de kafamdaki etkinlikleri çoğu zaman yapamayabiliyorum çünkü zaten haftada 6 saatlik bir dersimiz var, zaman yetmiyor." (Ö14).

Öğretmenlerin yaratıcılığı temasıyla ilgili olarak oluşturulan kodlardan bir diğeri "Hazırcılığa sebep olma"dır. Bazı öğretmenler ders kitabına tamamen bağılı kalmanın öğretmeni hazırcılığa ittiğini ileri sürmektedirler. Bununla ilgili olarak Ö5'in "Ders kitaplarına tamamen bağlı kalırsanız hapsolmuş olursunuz. Bunu sürekli yapa yapa zaten burada var benim bir şey vermeme gerek yok diye düşünür bir öğretmen bence tamamen kitaba bağlı kalırsa." görüşü ile Ö18'in "Ders kitabına bağlı kalırsak hazıra konmuş oluyoruz. Yaratıcılığımızı bir parça köreltiyor." görüşleri örnek olarak gösterilebilir.

"Yaratıcılığı etkilememe" koduyla ilgili olarak iki öğretmen görüş belirtmiştir. Ö9 "Öğretmenin yaratıcılığını çok fazla etkileyeceğini düşünmüyorum." ifadesi ile Ö13 de "Kitap bir materyal benim yanımda, uygulanması gereken bir vasıta. Ben yine kafamdakileri uygularım, kendi bilgi birikimimi aktarıım, hayattan örnekler veririm. Biz okulda aynı zamanda hayatı öğreniyoruz. Tabi bu arada kitap da bize bir kılavuz. Oradaki etkinliklere bağlı kalmak, o etkinliklere değinmek bizi kısıtlamıyor." diyerek ders kitabına bağlılı̆ın öğretmenin yaratıcılığını etkilemediğini belirtmişlerdir.

Öğretmen yaratıcılığı teması kapsamında birer frekansa sahip olan kodlar "Sıradanlaştırma", "Süreci kontrol altında tutma isteği", "Üretkenliğin düşmesi", "Öğrencilerin sıkılması", "Ders kitaplarının ilgi çekmedeki yetersizliği" ve "Ders kitabının niteliği" dir.

\section{Sonuç}

Sonuç olarak ders kitaplarındaki metinlerin yeterli olduğunu düşündüklerinden dokuz öğretmenin yalnız ders kitaplarındaki metinleri kullandıkları, bunun dışında diğer öğretmenlerin önceliklerinin ders kitaplarındaki metinlere yer vermek olduğu görülmüştür. Bunun dışında metinlerin kazanımlara uygun olması ve etkinliklerin de metinlerin işlenmesini gerekli kılması gibi nedenlerle 
ders kitaplarına tam anlamıyla bağlı kaldıkları ortaya çıkmıştır. Ancak öğretmenlerin metinlerin öğrenci seviyesine uygun olmaması durumu ile ders işlenişinde metin çeşitliliğini sağlamak, öğrencileri güdülemek ve onlara hitap eden metni temin etmek gibi amaçlarla da farklı kaynaklardan metin kullandıkları anlaşılmıştır. Gündoğdu (2011) da araştırmasında sekizinci sınıf Türkçe ders kitabında bulunan dinleme metinlerinin içeriksel ve biçimsel açılardan dinleme becerisinin geliştirilmesinde birtakım yetersizlikler barındırdığını belirtmiştir. Türkçe öğretmenlerinin ders kitaplarına bağlııklarının araştıııldığı bu çalışmada bazı metinlerin öğrenci seviyesine uygun olmaması görüşü ile Gündoğdu'nun (2011) araştırmasında metinlerde birtakım yetersizliklerin bulunması benzerlik göstermektedir.

Etkinlikler bağlamında ders kitabına bağlılıkla ilgili olarak öğretmenlerin görüşleri incelenmiş ve önceliklerinin her zaman ders kitabı olduğu ve buna bağlı kaldıkları görülmüştür. Ancak etkinliklerin yetersiz veya gereksiz olduğunun düşünülmesi, öğrencileri liselere geçiş sınavına (LGS) daha iyi hazırlamak istemeleri, konuların anlaşımasının sağlanması ve pekiştirilmesi, etkinlik çeşitlerini zenginleştirme isteği vb. nedenlerle ders kitabına bağlılıklarını esnettikleri ve derslerde farklı kaynaklara da yer verdikleri görülmüştür. Tema sonu değerlendirmelerinin etkili olduğu düşünüldüğünden öğretmenler bu anlamda ders kitaplarına bağlı kalmaktadırlar. Ders kitaplarındaki etkinliklerin öğrenci seviyesine uygun olmaması durumunda öğretmen kitap dışına çıkmakta ve farklı kaynaklardan yararlanmaktadır. Katılımcılardan bazıları ders kitabındaki etkinlikleri yeterli gördüğünden kitaba tamamen bağlı kalmaktadır. Dolayısıyla etkinliklerin yeterliliği de bağlılı̆ı etkilemektedir. Ayrıca ders kitabındaki etkinlikler hep aynı tarzda olduğunda öğrenci sıkılmakta veya yapamayacağını düşündüğünden olumsuz bir önyargı geliştirebilmektedir. Bu nedenle öğretmen, rutinin dışına çıkmak isteyeceğinden kitaba bağlı kalamayacağı durumlar oluşabilmektedir. Araştırmada ders kitabında yer alan bazı etkinliklerin öğrencilerin ilgisini çekmekte yetersiz kalması görüşlerine dayalı olarak ulaşılan sonuç ile Nurlu ve Gülden'in (2018) araştırmalarında elde ettikleri, birbirini tekrar eden konular ile kurgusal açıdan öğrencinin ilgisini çekemeyen etkinliklerin sebep olduğu güdüleme yetersizliği sonucu benzerlik göstermektedir. Bunlara ek olarak öğretmenin eğitim verdiği sınıf kademesi de kitaba bağlııkta etkili olmaktadır. Şöyle ki, eğer 8. sınıfta ders işleniyorsa liselere giriş sınavına hazırlık söz konusu olacağından ders kitabına bağlı kalınmayarak farklı kaynaklardan yararlanılmaktadır. Bu doğrultuda Güneş ve Baki (2011) de araştırmalarında ulusal sınavlarda öğrencilerinin başarısız olacağı endişesiyle öğretmenlerin derslerde öğrenci merkezli etkinlikler yerine sınava yönelik test çözmeyi tercih ettiklerini belirtmişlerdir. Yaşar (2012) da araştırmasında veli ve öğrencilerin sınav odaklı ders işlenmesi yönünde isteklerinin olduğunu ortaya koymuştur.

Öğretmenlerin sahip oldukları alan bilgisi ile ilgili olarak ders kitaplarına bağlılıklarına bakıldığında 15 katılımcının ders kitabını bu anlamda yetersiz gördükleri, 7 katılımcının da alan bilgisi için farklı kaynaklara intiyaç duydukları ve dolayısıyla ders kitaplarına bağlı kalmadığı durumların olduğu görülmüştür. Ayrıca öğretmenin kendi alan bilgisine güvenmesi, meslekî tecrübesi, alan bilgisini tazeleme ihtiyacı duyması ve eğitim verdiği sınıf kademesi (5., 6., 7., 8. sınıf) gibi gerekçelerle ders kitaplarına bağlııklarını esnettikleri anlaşılmıştır. Bunlar dışında ders kitaplarındaki bilgilerin güncelliği, tartışmalı konuların kitaba bağıılığı gerektirmesi ve ders kitaplarının alan bilgisi için yeterli görülmesi gibi nedenler onların Türkçe ders kitaplarına bağlı kalmalarını sağladığını söylemek mümkündür. Şeref'in (2020) yaptığı araştırmada da, Türkçe öğretmenlerinin konu bilgilerindeki yetersizliği ders kitaplarına bağlılık nedeni olarak görmedikleri, kendilerini alan bilgisi açısından yeterli gördükleri belirtilmiştir.

Öğretmenlerin, öğrenci seviyelerine göre Türkçe ders kitaplarına bağlılıklarına ilişkin olarak yaptıkları değerlendirmelerde akademik başarısı yüksek öğrenciler için ders kitabındaki konuyu tamamladıktan sonra onlara uygun etkinlik ihtiyacı duyduklarını ve farklı kaynaklardan bu amaçla yararlandıklarını belirtmişlerdir. Yapılan görüşmelerden öğretmenlerin akademik başarısı düşük öğrencilerde konunun anlaşılması için ders kitaplarına bağlı kaldıkları, bunun dışına çıkmadan öğrencilerin seviyelerine uygun yöntemlerle konunun anlaşılmasına öncelik verdikleri anlaşılmıştır. Öztürk'ün (2003) yaptığı araştırmada öğrenci seviyelerinin yüksek olduğu sınıflarda öğretimin kolayca gerçekleştirilirken, düşük seviyeli öğrencilerin olduğu sınıflarda programın istenilen şekilde 
uygulanamamasında öğrencilerin dikkatlerinin kolayca dağılmasının etkili olduğu belirtilmiştir. Kaya vd.'ne (2012) göre öğrencilerin başarı düzeyi yüksekse öğretmenler öğretim programını hedeflendiği şekilde uygulayabilmekte, öğrencilerin başarı düzeyi düşükse hedeflerin ancak bazılarına ulaşılabilmektedir. Adı geçen çalışmalarda öğrenci seviyesi öğretim programının uygulanması açısından incelenmiştir. Türkçe öğretmenlerinin ders kitaplarına bağılıılarında öğrenci seviyesi bağlamında ulaşılan sonuçlarda sınıf seviyesinin öğretim programının uygulanmasıyla ilgili çalışmalarda olduğu gibi etkili olduğu görülmüştür. Bazı öğretmenlerin öğrencilerin seviyelerine uygun etkinlik sağlama gayretiyle kitaba bağlı kalmadıkları durumların olduğu, bazılarının da kitaba tamamen bağlı kalarak dersin içeriğini öğrencilerin seviyelerine uyarlayarak anlattıkları belirlenmiştir. Ders kitabındaki içeriğin öğrencilerin hazır bulunuşluk düzeylerine uygun olup olmamasının da kitaba bağlılıkta etkili olduğu, böyle durumlarda öğrencileri güdülemek ve etkili öğretimin yapılabilmesi için Türkçe ders kitabına bağlııkta esnekliklerin yapılabildiği ortaya çıkmıştır. Bunlara ek olarak ders kitabının öğrenci seviyesinin çok altında olduğu görüldüğü için kitaba bağlı kalmakla birlikte konuyla ilgili olarak araştırma ödevlerine yer verildiği belirlenmiştir. Dolayısıyla öğrencilerin akademik başarı düzeylerindeki farklılıklar ile öğrenme düzeylerindeki farklııklar öğretmenlerin ders kitaplarına bağlılığı üzerinde etkili olmaktadır.

Türkçe öğretmenleriyle ders kitaplarına bağılığın onların yaratıcılığını nasıl etkilediği ile ilgili olarak yapılan görüşmede, on bir katılımcının kitaba tamamen bağlı kalarak ders işlemenin öğretmenin yaratıcılığını olumsuz etkilediği görüşü ön plana çıkmıştır. Bunun dışında bazı katııımcıların görüşleri doğrultusunda ders kitabına bağlı kalmanın öğretmenlerin hazırcılığa iteceği kodu belirlenirken, bazılarına göre de ders kitabı kullanılması gereken bir araçtır ve öğretmen kendi usulüyle ders işlediği için onun yaratıcılığına da herhangi bir etkisi bulunmamaktadır. Araştırmada, ders kitabına tamamen bağlı kalmanın öğretmeni sıradanlaştırdığı ve üretkenliğini düşürdüğü görüşleri tespit edilmiştir. Bunlar dışında bir katılımcıya göre ders kitapları öğrencinin ilgisini çekmede yetersiz kaldığı için öğretmenin bu eksikliği giderme yolundaki gayreti onun yaratıcılığını artırmaktadır. Başka bir katıımcıya göre ders hedeflenen süreden önce ya da sonra bitebildiğinden kalan zamanı doldurmak öğretmenin elindedir ve süreci kontrol altında tutmak istemektedir. Bu istek de onun ders kitabına tamamen bağlı kalmasını engellemektedir. Bunlar dışında ders kitabının niteliği öğretmenin ders kitabına bağlılığında etkili bir faktördür. Basit ve niteliksiz bir ders kitabı öğretmenin yaratıcılığını olumsuz etkilerken, beceri temelli soruların ve etkinliklerin bulunduğu nitelikli bir ders kitabı da öğretmenin yaratıcılı̆ı̆ı ılumlu yönde etkilemektedir.

Türkçe öğretmenlerinin ders kitaplarına bağlılıkları ile ilgili olarak Öztürk (2019) bir ölçek geliştirmiş ve bu ölçekte cinsiyet, yaş, hizmet yılı, mezun olunan fakülte ve eğitim durumu değişkenleri ile bağlılık arasındaki ilişkiyi incelemiştir. Çalışma sonunda cinsiyet ve mezun olunan fakülte değişkenleri ile bağlılık arasında anlamlı bir fark bulunmazken; diğer değişkenler ile bağlılık arasında anlamlı bir fark bulunmuştur. Öztürk ve Çerçi'nin (2019) çalışması ile yirmi Türkçe öğretmeninin Türkçe ders kitaplarına bağlılıkları ile ilgili görüşlerinin değerlendirildiği bu araştırma arasında odak noktasının Türkçe ders kitaplarına bağlılık olması açısından ortaklık bulunmaktadır. Bunun dışında etkinlikler ve öğretmen yeterlilikleri ile alan bilgisi, her iki çalışmada da Türkçe öğretmenlerinin ders kitaplarına bağıııklarındaki ortak bakış açısıdır. Ancak her iki çalışma araştırma yöntemleri (nitel/nicel) açısından ve konuya yaklaşım açısından farklılık göstermektedir.

Araştırmada ulaşılan sonuçlardan hareketle sunulacak öneriler şunlardır:

1. Öğretmen adaylarına mesleğe başlamadan önce bölge, okul, sınıf ve öğrenci özelliklerini dikkate alarak uygulamada yapılabilecek değişiklikler/uyarlamalar hakkında eğitim verilmelidir.

2. Programın uygulanması sırasında öğrencilerin başarı ve algı düzeyleri arasındaki farklııktan kaynaklanabilecek sorunların çözümü için destekleyici yönergeler ve açıklamalar geliştirilmelidir.

3. Türkçe ders kitabında yer alan metinlerin hem dil bilgisel kazanım hem de içerik açısından tutarlı ve öğrencilerin ilgisini çekecek nitelikte olması gerekir.

4. Ders kitaplarında yer alan etkinlikler sıradanlıktan uzak ve hedeflenen sürede tamamlanabilecek uzunlukta olmalıdır.

5. Ders kitapları merkezî sınavlara hazırlık sürecini destekleyecek nitelikleri de barındırmalıdır. 


\section{Yazarların Katkı Oranı}

Çalışma tek yazarlı olup bütün araştırma sorumlu yazara aittir.

\section{Çıkar Çatışması}

Bu araştırmada çıkar çatışması teşkil edebilecek herhangi bir durum ya da ilişki yoktur.

\section{Destek ve Teşekkür}

Çalışmanın ortaya çıkmasında zaman ayırıp görüşmeye katılan bütün Türkçe öğretmenlerine teşekkür ederim.

\section{Kaynaklar}

Akın, E. (2015). Türkçe çalışma kitaplarındaki (6, 7 ve 8. Sınıflar) dil bilgisi etkinliklerinin çeşitli açılardan değerlendirilmesi. International Periodical For The Languages, Literature and History of Turkish or Turkic, 10(15), 19-34.

Baş, B. (2003). Altıncı sınıf Türkçe ders kitaplarındaki metin türleri üzerine bir inceleme. Türklük Bilimi Araştırmaları Dergisi, 13(1), 257-265.

Bümen, N. T., Çakar, E. \& Yıldız, D. G. (2014). Türkiye'de eğitim programına bağlııık ve bağlıı̆ı etkileyen etkenler. Kuram ve Uygulamada Eğitim Bilimleri, 14(1), 203-228.

Büyüköztürk, Ş., Kılıç çakmak, E., Akgün, Ö. E., Karadeniz, Ş. \& Demirel, F. (2013). Bilimsel araştırma yöntemleri, Ankara: Pegem Akademi.

Cunningham, D. J., Duffy, T. ve Knuth, R. (2000). "The textbook ofthe future" centre for research on learning and technology. Indiana University.

Cunningworth, A. (1995). Choosing your coursebook. Oxford: Heinemann ELT.

Çelik, T., Demirgüneş, S. ve Fidan, D. (2015). Okur dostu metin olma özelliği ile okuduğunu anlama başarısı arasındaki ilişkinin incelenmesi. Başkent University Journal of Education, 2(1), 115122.

Epaçan, C. ve Okçu, V. (2010). İlköğretim Türkçe ders kitaplarının öğretmen görüşleri doğrultusunda değerlendirilmesi. Milli Eğitim Dergisi, 182(2), 39-51.

Gedik, M., Pesen, A. \& Tekin, B. (2016). Türkçe ders kitaplarına yönelik Türkçe öğretmenlerinin görüşlerini belirleme çalışması - Siirt ili örneği. Akademik Bakış Dergisi, 58, 667-687.

Göçer, A. (2008). İlköğretim Türkçe ders kitaplarının ölçme ve değerlendirme açısından incelenmesi. Atatürk Üniversitesi Sosyal Bilimler Enstitüsü Dergisi, 11(1), 197-210.

Grant, N. (1987). Making the most of your textbook. Oxford: Heinemann Publishers Ltd.

Gündoğdu, A. E. (2011). İlköğretim sekizinci sınıf dinleme metinlerinin çeşitli değişkenler açısından incelenmesi. International Periodical For The Languages, Literature and History of Turkish or Turkic, 6(1), 1186-1196.

Güneş, B. ve Baki, A. (2011). Dördüncü sınıf matematik dersi öğretim programının uygulanmasından yansımalar. Hacettepe Üniversitesi Eğitim Fakültesi Dergisi,41, 192-205.

Güven, A. Z. (2014). 7. Sınıf Türkçe ders kitaplarında yer alan metinlerin metinsellik ölçütlerine göre değerlendirilmesi. International Periodical For The Languages, Literature and History of Turkish or Turkic, 9(8), 517-535.

Hayırsever, F. (2010). Sosyal bilgiler ders, öğretmen kılavuz ve öğrenci çalışma kitaplarının sosyal bilgiler öğretim programında kazandırılması hedeflenen temel beceriler açışından değerlendirilmesi (Yayımlanmamış Doktora Tezi). Ankara Üniversitesi Eğitim Bilimleri Enstitüsü, Ankara.

İşeri, K. (2010). Türkçe ders kitabındaki metinlerin metinsellik özellikler. Ülper, H. (Ed.), Türkçe ders kitabı çözümlemeleri (ss. 91-112). Ankara: Pegem Yayıncılık.

Kaya, E., Çetin, P. S. \& Yıldırım, A. (2012). Transformation of centralized curriculum into classroom practice: An analysis of teachers' experiences. International Journal of Curriculum and Intructional Studies, 2(3), 103-113.

Kaya, M. (2020). Metin uzunluklarının öğrenci başarısı etkisi ve öğrenmeleriyle ilgili görüşlerinin değerlendirilmesi. Electronic Turkish Studies, 15(1), 345-360. 
Kılıç, A. \& Seven, S. (2002). Konu alanı ders kitabı incelemesi. Ankara: Pegem Akademi Yayınları.

Miles, M. B. ve Huberman, A. M. (2015). Nitel veri analizi (Çev. S. Akbaba Altun, A. Ersoy). Ankara: Pegem.

Millî Eğitim Bakanlığı Ders Kitapları ve Eğitim Araçları Yönetmeliği. (2012). T.C. Resmi Gazete, 28409, 12 Eylül 2012.

Nurlu, M., ve Gülden, B. (2018). Yaparak-yaşayarak öğrenme felsefesi çerçevesinde Türkçe ders kitaplarına ortaokul öğrencilerinin eleştirel bakışı. Ağca, F. ve Koç, A. (Ed.), X. Uluslararası Dünya Dili Türkçe Sempozyumu Bildiri Kitabı (ss. 1150-1161). Eskişehir: Eskişehir Osmangazi Üniversitesi Yayınları.

Özbay, M. (2003) Türkçe öğretiminde hedef-araç ilişkisinin ders kitabı örneğinde değerlendirilmesi. Türklük Bilimi Araştırmaları Dergisi, 13(1), 59-69.

Öztürk, A. T. (2019). Türkçe öğretmenlerinin ders kitaplarına bağlılık durumları (Yayımlanmamış Yüksek Lisans Tezi). Gaziantep Üniversitesi Eğitim Bilimleri Enstitüsü, Gaziantep.

Öztürk, A. T. ve Çerçi, A. (2019). Türkçe öğretmenlerinin ders kitaplarına bağlılıkları ölçeğinin geliştirilmesi: geçerlilik ve güvenirlik çalışması. Ana Dili Eğitimi Dergisi, 7(4), 876-897.

Öztürk, E. (2003). An assessment of high school biology curriculum implementation (Yayımlanmamış Doktora Tezi) . Middle East Technical University, Ankara.

Susar Kırmızı, F. (2014). 4. sınıf Türkçe ders kitabı metinlerinde yer alan değerler. Değerler Eğitimi Dergisi, 12(27), 217-259.

Şeref, i. (2020). The investigation into the dependency level of Turkish language teachers on coursebooks. European Journal of Education Studies, 7(5), 163-174.

Türkiye Cumhuriyeti Anayasası (1982). T.C. Resmi Gazete, 17863, 9 Kasım 1982.

Türnüklü, A. (2000). Eğitimbilim araştırmalarında etkin olarak kullanılabilecek nitel bir araştırma tekniği: görüşme. Kuram ve Uygulamada Eğitim Yönetimi, 24, 543-559.

Yanpar Şahin, T., \& Yıldırım, S. (1999). Öğretim teknolojileri ve materyal geliştirme. Ankara: Anı Yayıncilık.

Yaşar, M. D. (2012). 9. Sınıf kimya öğretim programındaki yapılandırmacılı̆̆a dayalı öğelerin öğretmenler tarafından algılanışı ve uygulamasına yönelik bir inceleme: Erzurum örneği (Yayımlanmamış Doktora Tezi). Atatürk Üniversitesi Eğitim Bilimleri Enstitüsü, Erzurum.

Yazııı, E. ve Kurudayıoğlu, M. (2017). 5. Sınıf Türkçe ders kitaplarındaki dinleme metinlerinin öğrencilerin seviyesine uygunluğunun incelenmesi. Ana Dili Eğitimi Dergisi, 5(4), 967-984.

Yıldırım, A. ve Şimşek, H. (2011). Sosyal bilimlerde nitel araştırma yöntemleri. Ankara: Seçkin Yayıncilık.

Yin, R. K. (1984). Case study research: design and methods. Beverly Hills, CA: Sage.

Ünveren Kapanadze, D. (2018). Dil ve kültür aktarımında işlevsel bir araç olarak ders kitapları: Türkçe ders kitapları örneği. Turkish Studies Educational Sciences, 13(27), 1575-1592.

\section{Introduction}

\section{Extended Abstract}

It is necessary to e valuate the extent to adhere to the textbooks of Turkish language teachers in the context that Turkish is a skill-based lesson. Turkish language lessons are not only the lessons for transferring the information. It is also a lesson for students that they can find the reflection of it in their whole life and that they can apply their learning to the comprehension and narration areas. From this point of view it is necessary to evaluate the Turkish language teachers' adherence to the textbooks in the direction of some purposes, such as, making use of activities to improve four basic language skills, providing literary pleasure and delicacy, teaching grammar, endearing Turkish via passages, providing reading habit, developing vocabulary, making assessment and evaluation. The aim of this study is to determine the points of view of Turkish language teachers about their adherence to the textbooks. 


\section{Method}

This study is a qualitative research which is on evaluation of Turkish language teachers' opinions about their adherence to the textbooks. Twenty Turkish language teachers from six different secondary schools in Aksaray Provincial Directorate for National Education have been interviewed within the scope of the study. In order to analyze the interviews the content analysis method which is one of the qualitative research methods is used.

\section{Result and Discussion}

As a result of the study it is seen that 9 Turkish language teachers use only the texts in the textbooks because they find them enough, and the others use firstly the texts from the textbooks. Moreover, because of the coherence in the texts and the objectives, and because of the fact that the activities necessitate to be covered of the texts, the teachers stick to the texts completely. However it is understood that the teachers use also different sources in order to provide text variety, to motivate students and provide the texts appropriate to students' levels and interests. Gündogdu (2011) indicated in her research that the listening texts in $8^{\text {th }}$ grade Turkish language books are insufficient to improve listening skills both contextually and stylistically. Gündogdu's (2011) research results have a similarity on the opinions of teachers from this study about inappropriateness of some texts to the student levels.

Teachers' opinions have been analyzed on the context of activities and it has been seen that their priorities are always the textbooks and they stick to them. However, they have stretched the adherence to the textbooks and used different sources for some reasons such as existence of unnecessary or inefficient activities in textbooks, preparing the students to the high school entrance exam, providing a better understanding of the subjects and reinforcing the students, enriching the variety of activities etc. Because teachers think that the assessments in the end of the theme are important they adhere to the textbooks. In case the activities in the textbooks are inefficient or inappropriate for students levels the teachers benefit from different sources. Some participants in the study stick to the textbooks because they find the activities sufficient. It shows that the efficacy of the activities affects the adherence to the textbooks. The result of the study on the basis of opinions that some activities are insufficient to attract students' attention has similarities with Gülden and Nurlu's (2018) research results on inadequacy of motivation caused from repetitive topics or fictionally boring activities. In addition to that the grade level is also influential in adherence to the textbooks. For example, in $8^{\text {th }}$ grade, different sources can be used to be able to prepare students to the exam. Güneş and Baki (2011) indicated that teachers use tests instead of studentcentered activities with the worry of failure of students in general tests. Yaşar (2012) stated in his research that parents and students want to study by test focused.

When we look at the teachers' adherence to the textbooks in relation to their field knowledge, we see that 15 participants find the textbooks insufficient in this meaning, and 7 participants need to additional resources for field knowledge and so they don't stick to the textbooks. Moreover the teachers can flex the adherence to textbooks in concern with professional experience, need for refreshing the field knowledge, the grade level $\left(5^{\text {th }}, 6^{\text {th }}, 7^{\text {th }}, 8^{\text {th }}\right)$ that they teach and confidence of their field knowledge. Apart from these, because textbooks have up-to-date information, controversial topics necessitate to adherence to the textbooks and textbooks are sufficient for the field information it is possible to say that teachers adhere to the textbooks.

When we evaluate the teachers' adherence to the textbooks in terms of students' levels, we see that teachers use additional resources when academically successful students they finish the activities in textbooks early. In our interviews we see that when the students have low academic achievement, teachers adhere to the textbooks and they try to teach in a proper way for students' levels. Öztürk (2003) indicated that the teaching in the classes which have students with high academic success is carried out in an easy way however, in the classes which have students with low academic success, the curriculum hasn't been applied in a proper way because of the students' distractions. According to Kaya et al. (2012) if students have high academic achievement, teachers have reached the goals of the curriculum; if students have low academic success, teachers have 
reached only some of the goals of the curriculum. The mentioned study results are in the same direction with this study results on the context of effect of student level on Turkish language teachers' adherence to the textbooks.

In the interviews about the influence of adherence to the textbooks on creativity 11 participants state that entirely adherence to the textbooks affects the teachers' creativity in a negative way. Some participants think that adherence to the textbooks pushes teachers to laziness though some others think that textbook is just a tool and doesn't affect teacher's creativity because the teacher teaches in his or her own way. There are opinions in the study that entirely adherence to the textbooks makes teachers ordinary and decrease teachers' productivity. Apart from that according to a participant, because the textbooks are insufficient to attract students' attraction teachers make extra effort and it improves their creativity. According to another participant, the activity can finish early from the expected time and how-to-use the left time is up to the teacher and he/she wants to keep under control of the process. This effort prevents him or her to entirely adhere to the textbook. Moreover, the qualification of the textbook is another factor affecting the teachers' adherence to the textbooks. A Simple and unqualified textbook can change the teacher's creativity in a negative way, however, a textbook which have skill based questions and activities can affect the teacher's creativity in a positive way.

\section{Suggestions}

1. The prospective teacher should be trained about the changes/adaptations in application of curriculum considering the characteristics of region, school, class or students.

2. Supportive instructions and explanations should be given about the problems that may be emerged on the process of implementation of the program because of differences in success and perception levels of students.

3. The texts in Turkish language textbooks should be interesting and coherent both in terms of grammatical learning outcomes and content.

4. The activities in the textbooks should be out of ordinariness and in a proper length for finishing on time.

5. The textbooks should be supportive for the process of preparation to the general tests 